\title{
AKTUALISASI PROSES PENDIDIKAN NASIONAL PADA SILN DALAM ASIMILASI SIDH BELANDA DAN SIKL MALAYSIA
}

\author{
Husni Mubarok ${ }^{1}$, Vina Rosalia Fatma ${ }^{2}$, Nur Aisyah ${ }^{3}$, \\ Alfiyaturrohmah Wulandari ${ }^{4}$, Nilta Hidayah ${ }^{5}$, Fina Ni'matun Najah ${ }^{6}$ \\ Institut Agama Islam Negeri Kudus \\ husnimubarok@iainkudus.ac.id ${ }^{1}$, vinarosalia123@gmail.com²
}

\begin{abstract}
This study focuses on the teaching and learning process of Indonesian overseas schools (SILN). The purpose of making this article is to find out how the actualization of the national education process in SIDH Belanda dan SIKL Malaysia in assimilation in their country. This type of research is qualitative research. The method used is descriptive document analysis. And based on the analysis of various documents, it was found that the two countries implemented national education into teaching and learning activities. There are similarities and there are differences between the teaching and learning activities of the two countries. There are similarities and differences in the teaching and learning activities of the two countries, which are seen from three aspects, among others, national education in the curriculum, national values in the curriculum, and the strategy for implementing national education. In addion, Learning at Indonesian Overseas Schools (SILN) is also carried out optimally by SILN teachers in facing challenges and obstacles, this learning is carried out in order to realize and implement national education even though in overseas areas and to create smart and quality successors of the nation.
\end{abstract}

Keywords: Actualization, National Education, SILN, Assimilation

\begin{abstract}
Abstrak : Penelitian ini berfokus pada proses belajar mengajar Sekolah Indonesia Luar Negeri (SILN). Tujuan pembuatan artikel ini yaitu untuk mengetahui bagaimana aktualisasi proses pendidikan nasional yang ada di SIDH Belanda dan SIKL Malaysia dalam asimilasi di negaranya. Jenis penelitian ini adalah penelitian kualitatif. Metode yang digunakan adalah deskriptif analisis dokumen. Hasil dari penelitian ini ditemukan bahwa kedua negara tersebut mengimplementasikan pendidikan nasional ke dalam kegiatan belajar mengajar. Ada persamaan dan ada perbedaan dari kegiatan belajar mengajar kedua negara tersebut yaitu dilihat dari tiga aspek antara lain, pendidikan nasional dalam kurikulum, nilai-nilai nasional dalam kurikulum, dan strategi penerapan pendidikan nasional. Selain itu, pembelajaran di Sekolah Indonesia Luar Negeri (SILN) juga dilakukan secara maksimal oleh pengajar SILN dalam mengahadapi tantangan dan hambatan, pembelajaran ini dilakukan guna mewujudkan dan mengimplementasikan pendidikan nasional walaupun dalam wilayah luar negeri serta menciptakan penerus bangsa yang cerdas dan berkualitas.
\end{abstract}

Kata Kunci: Aktualisasi, Pendidikan Nasional, SILN, Asimilasi

Manazhim : Jurnal Manajemen dan Ilmu Pendidikan

Volume 3, Nomor 1, Februari 2021; 52-69

https:// journal.stitpn.ac.id/index.php/manazhim 


\section{PENDAHULUAN}

Pendidikan merupakan suatu proses dalam meningkatkan dan mengembangkan kemampuan diri setiap individu untuk dapat hidup dan melangsungkan kehidupan. Pendidikan ini adalah kunci terpenting dalam kehidupan sehari-hari, yang berarti semua manusia berhak mendapatkan pendidikan dan mengembangkan kemampuan yang dimilikinya tanpa terkecuali. Begitu juga dengan warga negara Indonesia (WNI) yang berada dan bertempat tinggal di luar Negeri. Walaupun mereka tinggal di luar negeri tetapi mereka juga berhak untuk mendapatkan pendidikan nasional. Sehingga dibentuklah Sekolah Indonesia Luar Negeri (SILN) sebagai akses warga negara indonesia dalam mengenyam pendidikan nasional.

Sekolah Indonesia Luar Negeri ini diselenggarakan dalam rangka memenuhi kebutuhan pendidikan warga negara Indonesia. Keberadaanya memiliki peran yang tidak berbeda dengan sekolah indonesia pada umumnya, yaitu berperan dalam mencerdaskan kehidupan bangsa sebagaimana yang tercantum dalam pembukaan UUD 1945.

Realitanya dalam implementasi pendidikan nasional SILN tidak semudah pelaksanaan sekolah di Indonesia pada umumnya. Hal ini dikarenakan adanya heterogenitas latar belakang peserta didik yang menjadi tantangan dalam belajar mengajar. Selain itu perbedaan corak sosial budaya yang dijalani membuat pembelajaran sedikit terhambat.

SIDH Belanda dan SIKL Malaysia merupakan Sekolah Indonesia Luar Negeri (SILN) yang membuka jenjang mulai dari PAUD, SD, SMP sampai dengan SMA. Tantangan yang juga dirasa oleh SIDH Belanda dan SIKL Malaysia yaitu penanaman pembentukan karakter nasionalis dalam asimilasi kondisi sosial dan budaya yang ada.

Nilai dari pendidikan nasionalis adalah nilai yang mengarah kepada cara berpikir, bersikap, serta berbuat, sehingga timbul rasa setia, peduli, dan menghargai terhadap bahasa, lingkungan fisik, sosial, budaya, ekonomi, dan politik dari bangsa. Contoh nilai karakter nasionalis seperti sikap mengapresiasi budaya sendiri, sikap menjaga kekayaan yang dimiliki budaya bangsa, sikap rela berkorban, unggul, 
berprestasi, cinta tanah air, sikap menjaga dan melindungi lingkungan, tata hukum, disiplin, sikap menghormati keberagamaan budaya, suku, dan agama. ${ }^{1}$

Sebagai Sekolah Indonesia Luar Negeri, maka diperlukan adanya penanaman pendidikan karakter nasionalis pada diri peserta didik, supaya mereka paham jati dirinya sebagai bangsa Indonesia. Pendidikan nasional ini dilaksanakan tidak hanya pada pembelajaran akademik saja tetapi juga dalam pembelajaran non akademik yang berada diluar sekolah. Terkait hal ini, peneliti sangat tertarik untuk menguji lebih dalam mengenai bagaimana proses penyesuaian pendidikan nasionalis peserta didik SIDH Belanda dan SIKL Malaysia dari adanya proses asimilisi akan terbentuk.

\section{METODE PENELITIAN}

Penelitian ini menggunakan jenis penelitian kualitatif. Penelitian kualitatif merupakan suatu metode penelitian yang digunakan dalam meneliti pada kondisi obyek yang alamiah. Berdasarkan jenis penelitian ini, metode yang digunakan adalah metode deskriptif analitis. Deskriptif berarti memaparkan sesuatu dengan kata-kata yang jelas dan terperinci. Analitis berarti penyelidikan terhadap suatu hal yang merupakan kebenaran dari permasalahan yang terjadi. Metode deskriptif analitis berarti suatu cara atau teknik penelitian yang digunakan berdasarkan atas pertimbangan dari permasalahan yang akan diteliti dan sedang terjadi. Tujuan dari penelitian ini adalah untuk mengetahui aktualisasi proses pendidikan nasional yang ada di SIDH Belanda dan SIKL Malaysia dalam asimilasi di negaranya. Untuk mengetahui permasalahan dalam penelitian ini, peneliti mengkaji dokumen kurikulum, dan dokumen-dokumen lainnya yang berkaitan dengan penerapan pendidikan nasional di kedua negara tersebut.

1 Agustinus Tanggu Daga, "Perbandingan Pendidikan Karakter Dalam Kurikulum Sekolah Dasar Di Malaysia, India, dan Indonesia.” Jurnal Edukasi Samba (JES). Vol. 4. No. 1. (2020), hlm 5 


\section{HASIL DAN PEMBAHASAN}

\section{Hasil Penelitian}

\section{Sistem Pendidikan Nasional}

Pendidikan merupakan suatu hal dasar dan pokok dalam membentuk karakter manusia yang bermasyarakat dan berbudaya. Pendidikan merupakan sebuah kewajiban bagi warga indonesia demi meningkatnya kualitas pembangunan bangsa, sebab dasar pembangunan salah satunya adalah pendidikan.

Pendidikan nasional adalah pendidikan dengan berlandaskan pada pancasila dan UUD 1945, serta berpedoman pada nilai-nilai agama, kebudayaan yang ada di Indonesia, dan cekatan dalam menghadapi kemajuan zaman. ${ }^{2}$ Pendidikan nasional dapat terwujud dengan adanya kolaborasi antara masyarakat, pemerintah, dan pelaksana pendidikan (Guru).

Fungsi pendidikan nasional menurut UU Nomor 20 Tahun 2003 Pasal 3 menyatakan bahwa fungsi pendidikan nasioanal yaitu mengembangkan keahlian yang dimiliki peserta didik, dan pembentukan karakter berbangsa dan bermartabat untuk mencerdaskan kehidupan bangsa. ${ }^{3}$ Alasan pembentukan karakter, untuk menanamkan nilai-nilai perilaku yang berhubungan dengan Tuhan Yang Maha Esa, diri sendiri, orang lain, lingkungan masyarakat, dan kepada bangsa yang diwujudkan melalui pikiran, sikap, perasaan, perkataan, dan perbuatan yang sesuai dengan normanorma agama, hukum, tata krama, budaya, dan adat istiadat.

Pendidikan nasional bertujuan untuk mengembangkan potensi yang dimiliki peserta didik dalam hal keimanan, dan bertakwa kepada Tuhan Yang Maha Esa, berakhlak muliaa, sehat, berilmu, cakap, kreatif, mandiri, demokratis, dan tanggung jawab. Seperti yang ditekankan pada pernyataan diatas, bahwa pelaksanaan

2 Lukman Hakim, "Pemerataan Akses Pendidikan Bagi Rakyat Sesuai Dengan Amanat Undang-Undang Nomer 20 Tahun 2003 Tentang Sistem Pendidikan Nasional, Jurnal EduTech. Vol. 2 No.1, Maret (2016). 55

3 Titik Sunarti Widyaningsih, dkk. "Internalisasi Nilai-nilai Karakter Pada Siswa SMP Dalam Prespektif Fenomologis." Jurnal Pembangunan Pendidikan: Fondasi dan aplikasi. 2(2). (2014) 
pendidikan nasional memiliki peranan penting dalam menciptakan generasi penerus bangsa dengan mempunyai nilai-nilai yang lebih baik. ${ }^{4}$

Pada dasarnya pendidikan nasional merupakan suatu kekuatan (power). Theodore Brameld (1965) menyatakan bahwa education is power, artinya manusia yang berpendidikan dapat menguasai dunia karena kecerdasannya. Pengertian tersebut semakin diperkuat oleh Francis Bacon (Brameld, 1965) berpendapat bahwa "Knowledge is power". Kemudian diperkuat lagi dengan adanya sabda Rasulullah saw, yaitu: Barang siapa umat yang mempunyai keinginan untuk memimpin dunia hendaknya menguasai banyak ilmu, barang siapa umat yang menghendaki akhirat hendaknya mereka menguasai ilmu, dan barang siapa umat yang berkeinginan menguasai keduannya dunia dan akhirat, hendaknya menguasai ilmu. Dari pernyataan tersebut menyebabkan adanya keyakinan akan pentingnya pendidikan nasional dalam kehidupan berbangsa dan bernegara. Melihat akan peran dan posisi pendidikan nasional yang sangat penting, maka terciptalah visi pendidikan yang tertera dalam UU No. 20 tahun 2003 tentang Sistem pendidikan Nasional yaitu terciptanya sistem pendidikan yang bersosial, berwibawa dalam meningkatakan kualitas manusia, sehingga dapat memperaktif manusia dalam menghadapi tantangan zaman.

Dalam menegakkan Sistem Pendidikan Nasional hendaknya mampu memberikan makna bagi kehidupan bangsa dengan melalui beberapa strategi. Pertama, Gerakan peduli pendidikan. Strategi yang digunakan ini berharap agar dapat mendorong semua pihak untuk ikut andil yang sebesar-besarnya terhadap terjadinya praktek pendidikan yang efektif, baik pendidikan formal, non formal, maupun informal. Karena pendidikan dilihat sebagai upaya yang strategis dalam memanusiakan maunusia. Kedua, Semua mengawal mutu. Mutu bagi pendidikan sangatlah berarti untuk mengangkat martabat individu, masyarakat dan bangsa. Karena itu semua pihak yang terdiri dari guru, orang tua, kepala sekolah, dan terutama peserta didik sendiri menjadi salah satu faktor terpenting dalam menentukan mutu pendidikan. Keseriusan dan komitmen yang tinggi menjadikan kunci utama dalam mengantarkan mutu pendidikan. Ketiga, Pendidikan moral menjadi

${ }^{4}$ Undang-undang Republik Indonesia Nomer 20 Tahun 2003, Pasal (3) Tentang Sistem Pendidikan Nasional. 
tanggung jawab semua. Untuk menjamin kedamaian hidup khususnya di Indonesia, karena setiap insan perlu membekali diri dengan pendidikan moral yang memadai, sehingga dapat mencapai kehidupan bahagia dunia dan akhirat. Oleh karena itu diharapkan agar semua pihak dapat berpartisipasi secara ikhlas untuk mengawal pendidikan moral baik di rumah, sekolah, maupun masyarakat. Keempat, Political will para eksekutif dan legislatif. Adanya political will para eksekutif dan legislatif memiliki kontribusi yang berarti bagi perumusan kebijakan dan jaminan peraturan perundangundangan yang memperlancar proses pendidikan yang bermutu bagi semua warga negara, tanpa terkecuali. Namun perlu dicatat, sebagaimana yang dikemukaan oleh Tilaar (2006) bahwa pentingnya membangun manusia yang utuh melalui pendidikan nasional seharusnya dihindari dari kepentingan politik. Kelima, Pemantapan pendidikan seumur hidup, maknanya manusia hidup selalu dihadapkan dengan berbagai tantangan dan persoalan hidup.. Untuk menjamin eksistensi kehidupan berbangsa dan bernegara, baik untuk mendapatkan kebahagian di dunia maupun di akhirat, sehingga pendidikan seumur hidup menjadi kebutuhan setiap orang di Indonesia, tanpa terkecuali. Dapat kita ketahui, bahwasanya salah satu prinsip-prinsip pendidikan nasional, yaitu life long learning. Keenam, Perlunya menjaga konsistensi inovasi pendidikan. Pembaharuan pendekatan atau paradigma pendidikan yang berterkaitan dengan praktek pendidikan akan lebih bermakna apabila tetap dijaga konsistensinya dengan sistem pendidikan nasional dan pandangan terhadap peserta didik sebagai insan Indonesia yang utuh. Jika hal tersebut tidak mendapatkan perhatian yang cukp, bisa jadi kehadiran inovasi dalam pendidikan bersifat pragmatis dan tidak memiliki nilai ideal. ${ }^{5}$

\section{Asimilasi SIDH Belanda dan SIDH}

Asimilasi merupakan proses penyesuaian pola kebudayaan asli dengan budaya yang menjadi mayoritas. ${ }^{6}$ Setelah perkembangannya, pengertian asimilasi ini

\footnotetext{
5 Rochmat Wahab, "Menegakkan Sistem Pendidikan Nasional Berdasarkan Pancasila." (Yogyakarta: UGM, 2010) hlm. 7-8

'Soejono Soekanto, "Sosiologi : Suatu Pengantar", Jakarta: Rajawali Grafindo Persada, 1983), hlm.38
} 
bermakna suatu proses sosial dalam usaha untuk meminimalisir perbedaan yang ada disuatu tempat dan sekelompok orang. ${ }^{7}$

Macam-macam asimilasi antara lain: (1) Asimilasi budaya dan perilaku, atau lazim disebut dengan akulturasi. Maksudnya terjadi perubahan pola-pola kebudayaan ke arah penyesuaian terhadap kebudayaan kelompok mayoritas (2) Asimilasi struktural, yaitu tergabungnya sesorang kedalam berbagai jenis perkumpulan, klik, kelembagaan kelompok mayoritas, khususnya untuk orang-orang yang berada dilevel dasar atau orang yang levelnya paling rendah. (3) Asimilasi perkawinan, terjadinya perkawinan campuran dalam skal besar. (4 asimilasi identifikasi, yaitu adanya pertambahan dari perasaan sebagai satu bangsa yang utuh. (5) Asimilasi penerimaan sikap, yaitu suatu asimilasi yang dicerminkan oleh tidak munculnya suatu sikap berprasangka. (6) Asimilasi penerimaan perilaku, yaitu asimilasi yang dicerminkan dengan adanya sikap tidak deskriminasi. (7) Asimilasi kewarganegaraan. Merupakan asimilasi yang terkait dengan status kewarganegaraan, antara lain tidak adanya konflik nilai dan konflik kekuatan atau yang lainnya. ${ }^{8}$

a. Asimilasi SIDH Belanda

Berdasarkan sistem pendidikannya, SIDH merupakan sekolah asing dengan menanamkan nilai-nilai Nasionalisme dan nilai-nilai keagamaan yang disesuaikan dengan sekolah yang ada di Indonesia sendiri. Sekolah Indonesia Den Haag memiliki jenjang mulai SD, SMP, dan SMA yang sudah mendapatkan Akreditasi A Sekolah SDIH mempunyai dua bahasa pengantar yaitu: bahasa Inggris sebagai bahasa resmi dan bahasa Pranets.

Pada hakikatnya lembaga pendidikan SIDH (Sekolah Indonesia Den Haag) di bawah naungan KBRI yang mana sama kayak di Indonesia berdasarkan kurikulum beserta akademiknya yaitu menggunakan kurikulum sama seperti di Indonesia yaitu Kurikulum 2013, dan menggunakan pembelajaran secara tematik yang telah berlaku selama kurang lebih 6 tahun. Mungkin yang membuat berbeda adalah dengan ketersediaan dan kelengkapan media penunjang praktek pembelajaran. Di SIDH tidak mudah

\footnotetext{
${ }^{7}$ Apriana, “Asimilasi Kultural Arab-Melayu Palembang”, Jurnal Studi Islam, 15.2 (2019), 202

${ }^{8}$ Komsahrial Romli, “Akulturasi dan Asimilasi Dalam Konteks Interaksi Antar Etnik.” Jurnal Ijtimaiyya, Vol.8 No.1, Februari 2015. hlm 3
} 
dalam menambah gedung ruang kelas dikarenakan ada aturan tersendiri dari Belanda dalam penambahan gedung. mereka juga tidak mempunyai alasan untuk tidak menerima peserta didik jika ingin sekolah di SIDH.

SIDH menggunakan buku yang sama yaitu BSE, untuk kelas reguler ataupun pembelajaran jarak jauh (PJJ). Yang membedakan antara reguler dengan pembelajaran jarak jauh adalah waktu. Untuk pembelajaran jarak jauh waktu belajarnya di persempit karena keterbatasan waktu, selain itu juga dikarenakan sebagian besar siswa sudah belajar disekolah lokal. Maka dengan ini diperlukan bimbingan orang tua untuk membimbing anaknya dalam proses belajar. Untuk kelas reguler di SIDH sama prosesnya seperti sekolahsekolah yang ada di Indonesia.

Keistimewaan di SIDH adalah tetap menanamkan sikap nasionalisme dan cinta tanah air meski di negara orang. Yang menjadi tantangan di SIDH yaitu disana tetap mengajarkan pencak silat, tari-tarian dan semua hal yang berbau lokal dari Indonesia. Keunggulan tersendiri dari SIDH guru bisa fokus dalam mengajar karena hanya berisi 21 siswa berbeda dengan Indonesia yang bisa berisi hingga 30 siswa lebih dan Peserta didik sekolah indonesia belanda berasal dari warga indonesia sendiri atau warga keturunan yang berada di belanda dan sekitarnya, karena dekatnya jarak antara 1 negara dengan negara yang lain. Siswa SIDH Belanda juga sering mengikuti ajang Internasional yang mana pesertanya perwakilan dari negara-negara, di SIDH tidak ada event olimpiade atau porsema seperti di Indonesia. ${ }^{9}$

Sekolah indonesia Den Haag adalah salah satu sekolah yang berdiri di kawasan luar negeri yang di sesuaikan dengan kultur indonesia dimana dalam kurikulum pembelajaran, mata pelajaran dan tenaga pendidik nya dari Indonesia, Sekolah Indonesia Den Haag didirikan agar warga Indonesia yang berada di Den Haag dan sekitarnya dapat terfasilitasi pendididkan Indonesia, meski harus bersaing dengan sekolah lokal yang ada di belanda.

9 PGMI IAIN Kudus, "Kuliah Lapangan di Belanda-Prodi PGMI." Diakses dari https://youtu.be/1EF03L4ysmE. Pada tanggal 15 Desember 2020 
Secara lebih khusus, sistem pendidikan SIDH Belanda berusaha untuk mencapai tujuan pendidikan nasional dengan: (1) Melaksanakan keadilan terhadap ideologi masyarakat, (2) Meningkatkan minat belajar dan bersikap adil kepada masyarakat lain, (3) Meningkatkan pertukaran budaya, (4) Meningkatkan gerak sosial dan penyesuaian perbedaan unsur-unsur di masyarakat , (5) Meningkatkan angka kemakmuran dan kesejahteraan masyarakat, (6) Melatih siswa dan mengembangkan kemampuannya sesuai keahliannya, (7) Meningkatkan demokratisasi dan emansipasi, (8) Meningkatkan desentralisasi administrasi dan manajemen, (9) Meningkatkan inovasi budaya.

b. Asimilasi SIKL Malaysia

Malaysia merupakan sebuah negara yang memiliki masyarakat yang majemuk dengan bangsa Melayu, Cina, India, dan lainnya, serta memiliki agama yang bervariasi seperti Islam, Budha, Hindu, dan, Kristen. Pendidikan Indonesia di Malaysia salah satunya adalah SIKL Malaysia, dengan pelaksanaan pendidikan yang dijalankan mengikuti pendidikan nasional. SIKL Malaysia memiliki 5 program workshop untuk guru SIKL salah satu program tersebut penyusunan kurikulum yaitu penyelarasan kurikulum yang sekarang dikenal dengan kurikulum darurat. Penyelarasan kurikulum yaitu kurikulum yang ada dengan mengacu K13 diselaraskan, diekstrak menurut peta kesulitan sesuai dengan peta perkembangan. Ini bertujuan untuk mempermudah guru membuat rencana belajar mengajar yang lebih sesuai dengan kondisi belajar anak yaitu belajar dirumah dan disekolah. SIKL juga telah membuat salah satu aplikasi yaitu aplikasi RPP digital, aplikasi ini juga sudah menjawab guru yang sering diberatkan dengan beban admistrasi dalam pembuatan RPP.

Salah satu penerapan kurikulum di SIKL Malaysia adalah Living Curriculum. Konsep kurikulum ini diterapkan dengan adanya penyelarasan atau tetap mengacu pada kurikulum nasional, akan tetapi kurikulum tersebut digunakan dan dirumuskan sesuai dengan kebutuhan anak-anak didik yang berdomisili di Malaysia, sebab kondisi siswa di Malaysia jauh berbeda dari pada siswa di Indonesia sendiri. Tidak hanya itu, Living Curriculum ini juga membekali anak-anak untuk bertanggung jawab dan membina karakter 
selama belajar di rumah Konsep Living Curriculum adalah sebuah konsep yang lebih mengarah kepada proses holistik yang secara utuh atau menyeluruh dengan melibatkan semua pihak. Living kurikulum ini diterapkan di SIKL Malaysia dengan penyelarasan atau tetap mengacu pada kurikulum nasional namun digunakan dan dirumuskan sesuai dengan kebutuhan anak-anak didik yang berdomisili di Malaysia, sebab kondisi siswa di Malaysia jauh berbeda dari pada siswa di Indonesia sendiri. Tidak hanya itu, Living Curriculum ini juga membekali anak-anak untuk bertanggung jawab dan membina karakter selama belajar di rumah. ${ }^{10}$

Dengan di terapkannya living curiculum ini di harapkan siswa mampu mempunyai karakter yang baik dan mempunyai keterampilan yang cakap sehingga tidak hanya mengacu pada ilmu pengetahuan saja. Dalam hal ini tentu saja siswa dapat bercerita dan mengulang kembali pembelajaran yang di dapat. ${ }^{11}$ Berdasarkan penerapan Living Curriculum tersebut, berarti bahwa kurikulum pendidikan SIKL Malaysia sudah sesuai dengan teori pendidikan Indonesia itu sendiri. Bukti kesesuaian kurikulum SIKL Malaysia dengan kurikulum Indonesia antara lain:

a. SIKL Malaysia terdapat pendidikan interaksional yaitu pendidikan dengan menggunakan bahan ajar yang diambil dari lingkungan sosial - budaya yang dihadapi para siswa sekarang. Mereka dituntut untuk ikut menghayati nilai- nilai social-budaya yang menjadi ciri khas masyarakat sekitar, menilai secara kritis, selanjutnya mengembangkan pendapatnya sendiri terhadap berbagai aspek kehidupan masyarakat.

b. Kesesuaian kurikulum SIKL Malaysia dengan teori pendidikan kognitivisme. Dimana dalam pembelajaran lebih mementingkan proses belajar daripada hasil belajar, hal itu bisa dilihat pada proses pembelajaran yang lebih mengutamakan pembinaan karakter daripada nilai yang didapat dalam proses pembelajaran.

10 SIKL Channel TV, "Komite Sekolah Mendukung Implementasi Living Curriculum di SIKL.” Diakses dari https://youtu.be/65IIffHSr4E. Pada tanggal 15 Desember 2020.

${ }^{11}$ SIKL Channel TV, "Tanya Jawab-Living Curriculum SIKL Bersama Ketua Tim Penyusun Kurikulum-Ibu Dewi Mariani, S.Pd.” Diakses dari https://youtu.be/K9pEWyhKess. Pada tanggal 15 Desember 2020. 
c. Kesesuaian kurikulum SIKL Malaysia dengan teori pendidikan kontruktivisme. Dimana dalam pembelajaran, siswa adalah subjek utama dalam penemuan pengetahuan, siswa dituntut untuk menyusun dan membangun pengetahuan melalui berbagai pengalaman yang memungkinkan terbentuknya pengetahuan. Siswa dituntuk untuk ikut aktif dalam pengalamannya yang dapat menggali pengetahuan dan wawasan baru. Hal itu bisa dilihat dari adanya program yang diselenggarakan di SIKL Malaysia, yaitu pojok literasi yang bisa digunakan siswa sebagai penambah wawasan pengetahuan dalam proses pembelajaran.

d. Kesesuaian kurikulum SIKL Malaysia dengan teori pendidikan humanistik. Teori yang ini lebih memfokuskan pada manusia dalam mencari dan menemukan keahlian yang dimiliki dan mampu meningkatkan keahlian tersebut. Bisa dilihat dalam proses pembelajaran di SIKL Malaysia dimana siswa dituntut untuk mencari dan mengembangkan kemampuan yang dimilikinya, yang pada akhirnya kemampuan tersebut dituangkan dalam SIKL Expression Stage yaitu panggung kreasi siswa yang berkaitan dengan bakat, minat, dan seni.

e. Kesesuaian kurikulum SIKL Malaysia dengan teori pendidikan menjadikan hal dasar dalam kelancaran pelaksanaan pendidikan. Oleh sebab itu, pihak guru selaku pengajar harus selalu memegang landasan kurikulum yang sesuai dengan teori pendidikan, agar proses pembelajaran berjalan dengan baik dan pastinya sesuai dengan pembelajaran yang ada di Indonesia yang menganut pada kurikulum 2013

\section{PEMBAHASAN}

\section{Aktualisasi Pendidikan Nasional dalam Asimilasi di SIDH Belanda dan SIKL Malaysia}

Aktualisasi adalah suatu bentuk pelaksanaan, perwujudan, atau pengejawantahan dari apa yang sudah direncankan (AKA Kamarulzaman, 
Dahlan Y, 2005: 23), dalam kedudukan lain kata aktualisasi pendidikan nasional berarti kegiatan secara bersama-sama dalam mewujudkan pendidikan nasional demi mencerdaskan kehidupan bangsa.

Berdasarkan UU Nomer 20 Tahun 2003, kurikulum mempunyai dua aspek, pertama, kurikulum sebagai as plan (rencana) maksudnya, kurikulum dijadikan sebagai pedoman yang telah direncanakan sebelum pelaksanaan proses pembelajaran dan pengaturan isi. Kedua, cara pelaksanaan (method of implementation). Aspek ini digunakan untuk usaha dalam mencapaii tujuan pendidikan nasional. ${ }^{12}$

a. Strategi dalam merealisasikan atau mewujudkan pendidikan nasional dalam asimilasi SIDH Belanda

Dalam penyelengaraan kegiatan belajar mengajar di SIDH, guru yang mengajar hanya ada 2 pada jenjang SD, sedangkan pada jenjang SD ini dibagi menjadi 2 jenjang, yaitu kelas besar dan kelas kecil,kelas besar yang terdiri dari kelas 5 dan kelas 6, dan kelas kecil terdiri dari kelas 1,2,3,4. Di SIDH guru mengajar di dalam satu waktu dalam jenjang yang berbeda, jadi jika mengajar di kelas 5 dan 6, kelas 5 di ajar dan kelas 6 diberi tugas, untuk kurikulum yang digunakan yaitu menggunakan K-13, buku yang digunakan dari BSE, untuk saat ini masa pandemi dilakukan pembelajaran jarak jauh (pji) pembelajarannya menggunakan file yang juga dari BSE, ketika ujian untuk kelas 6 sebenarnya para siswa dari semua negara yang belajar di SIDH hadir di SIDH untuk ujian, tapi untuk tahun ini dilaksanakan secara online. ${ }^{13}$

Pembelajaran di SIDH Belanda dengan menggunakan metode pembelajaran interaktif dan model pembelajaran bermain dimana pembelajaran tersebut melibatkan peserta didik secara langsung dalam berbagai jenis kegiatan di dalam kelas. Model pembelajaran seperti ini membuat peserta didik saling berinteraksi antar satu dengan yang lain dalam berbuat dan berfikir yang dapat menghasilkan proses umpan balik

${ }^{12}$ Ade Suhendra, "Implementasi Kurikulum 2013 dalam Pembelajaran SD/MI Teori dan Aplikasi di Sekolah Dasar/ Madrasah Ibtidaiyyah (SD/MI).”( Jakarta Timur: Kencana, 2019)

13 PGMI IAIN Kudus, "Kuliah Lapangan di Belanda-Prodi PGMI." Diakses dari https://youtu.be/lEF03L4ysmE. Pada tanggal 15 Desember 2020 
secara langsung terhadap pembelajaran yang disampaikan. Karena keterbatasan pendidik di SIDH pengelolaan manajemen di sekolah tersebut juga menerapkan model multi subyek. Fungsi dari model ini adalah untuk memenuhi kebutuhan dari kekurangan jumlah guru di sekolah. Misalnya di SIDH setiap satu orang guru mengajar dalam satu waktu dijenjang yang berbeda. Jadi ketika guru bertugas mengajar di kelas kecil dan besar (2 dan 5).

Karena kondisi tersebut, maka guru haru siap menghadapi segala keadaan, tetapi berkat jam terbang guru yang sudah banyak maka dalam mengajar satu waktu dalam 2 kelas sudah bisa diatasi, jadi jika mengajar 2 kelas maka kelas yang satu di ajar, dan kelas yang lain di beri tugas, untuk kelas besar selama ini sudah mandiri jadi di kasih bahan terus mengerjakan tugas sendiri, jadi guru tersebut bisa mengajar di kelas lain, berbeda jika mengajar di dua kelas sekaligus, mengajar di tiga kelas sekaligus lebih sulit karena kondisi siswa yang berbeda - beda, maka campur tangan orang tua sangat penting untuk menjelaskan lagi materi di sekolah.

b. Strategi dalam merealisasikan atau mewujudkan pendidikan nasional dalam asimilasi SIKL Malaysia

Penerapan pendidikan nasional dalam asimilasi SIKL Malaysia yaitu dengan menerapkan dan menanamkan pendidikan karakter dalam kurikulum. SIKL Malaysia memberikan pendidikan karakter dalam bentuk pendidikan moral dan agama. ${ }^{14}$ Pendidikan moral ini mengajarkan penerapan nilai-nilai murni seperti yang ditekankan oleh kurikulum di kelas yang dilakukan dengan pengajaran secara langsung (direct teaching), dengan mengintegrasi pada mata pelajaran lainnya. Contoh nilai murni seperti kemandirian, menghargai, menghormati, kasih sayang, bersyukur dan lainnya. Pengajaran nilai moral merupakan bentuk penanaman

14 Prodi BKPI, "Kuliah Kerja Lapangan di Sekolah Indonesia Kuala Lumpur Malaysia." Diakses dari https://youtu.be/bZqI8Hdk0Ec. Pada tanggal 15 Desember 2020. 
pendidikan karakter yang sudah lama diketahui merupakan suatu proses yang saling berhubungan. ${ }^{15}$

Contoh kegiatan penerapan pendidikan karakter antara lain: (1) Kelas tanpa piket merupakan program yang bertujuan untuk melatih tanggung jawab, kedisiplinan, dan kerja sama antara peserta didik yang satu dengan yang lainnya, (2) Kantin kejujuran, program ini merupakan salah satu program pembinaan karakter bagi peserta didik. Program ini bertujuan untuk meningkatkan, mengamalkan, dan mempraktikkan nilai-nilai kejujuran masing-masing peserta didik dalam kehidupan bermasyarakat, (3) SIKL chanel TV, merupakan salah satu wadah kreasi untuk mengasah bakat dan minat di bidang Broad Casting dan media, (4) SIKL expression stage (panggung bakat minat), merupakan program panggung kreasi siswa yang berkaitan dengan bakat, minat dan seni. Di expression stage ini, anak-anak dalam seminggu bebas menampilkan bakat dan minatnya, serta kemampuan yang dimiliki dalam dirinya. SIKL expression stage ini berada di semua jenjang mulai dari TK, SD, SMP, sampai SMA. (5) Librrary explorace, merupakan kegiatan mengeksplor buku. Eksplorasi buku ini terjalin dengan adanya kerja sama antara pihak SIKL dengan perpustakaan negara Malaysia, (6) Pojok literasi, merupakan peningkatan budaya literasi melalui kegiatan pojok baca yang bertujuan untuk membiasakan siswa membaca buku. Sehingga masing-masing anak memiliki kartu cinta baca yang berfungsi untuk mengetahui seberapa banyak buku yang sudah dibaca anak dan akan mendapat reward di akhir semester. ${ }^{16}$

Mengadakan penyelarasan kurikulum dengan disesuaikan pada pendidikan nasional yaitu penyelarasan kurikulum yang ada dengan mengacu K13 diselaraskan, diekstrak menurut peta kesulitan sesuai dengan peta perkembangan. Ini bertujuan untuk mempermudah guru membuat rencana belajar mengajar yang lebih sesuai dengan kondisi

\footnotetext{
15 Bambang Sumintono, dkk, "Pendidikan Moral Di Malaysia: Tantangan dan Implementasi Pendidikan Karakter Di Sekolah.” Jurnal Pendidikan Karakter, Tahun II Nomor 1, Februari 2012

16 PGMI IAIN Kudus,. "Kuliah Lapangan di Belanda-Prodi PGMI." Diakses dari https://youtu.be/lEF03L4ysmE. Pada tanggal 15 Desember 2020
} 
belajar anak yaitu belajar dirumah dan disekolah. Pendidikan nilai karakter di SIKL Malaysia dilakukan dengan menggunakan metode interaksi sosial yang dilakukan ketika pembelajaran di sekolah maupun di luar sekolah

\section{Hambatan dalam perwujudan Pendidikan Nasional di SIDH Belanda} dan SIKL Malaysia

Hambatan dalam mengimplementasikan pendidikan nasional di SIDH Belanda dan SIKL Malaysia adalah sebagai berikut:

a. Hambatan penerapan pendidikan karakter di SIDH Belanda

Dalam bidang pengajaran yaitu kurangnya guru yang mengakibatkan siswa tidak dapat terkontrol dengan baik. Dikarenakan satu guru disuruh untuk memegang 2 kelas dalam satu waktu. Jadi siswa tidak dapat memahami sepenuhnya dalam menjalankan pembelajaran. Kenapa di sekolahan tersebut kekurangan guru dalam menjalankan pembelajaran? Karena guru di Indonesia kurang adanya minat dalam menjalankan tugas pengajar di Belanda. ${ }^{17}$

Hambatan selanjutnya yaitu fasilitas, kurangnya tempat dalam belajar karena sekolah terlalu sempit, dikarenakan bangunan SIDH Belanda didirikan atas hibahan dan di sekolahan tersebut tidak dapat pindah dan membangun bangunan baru di karena bukan tanah milik Indonesia.

Kesulitan belajar dalam pergantian kondisi geografi. Karena musim yang ada dibelanda dan indo berbeda banyaknya musim yang ada di Belanda contohnya musim gugur, hujan, salju, semi dll. Yang mengakibatkan siswa belajar di rumah atau secara online jadi belajar siswa indonesia dan Belanda sangat berbeda tetapi kurikulum sama seperti Indonesia yaitu kurikulum K13

Sarana prasarana di SIDH minim dan jauh dari sarana prasarana pendidikan di Indonesia. Kendala terbesar terdapat pada prasarana gedung yang masih ada dibawah kementrian luar negeri. Gedung yang kecil dan

17 PGMI IAIN Kudus, "Kuliah Lapangan di Belanda-Prodi PGMI." Diakses dari https://youtu.be/lEF03L4ysmE. Pada tanggal 15 Desember 2020 
ruang kelas yang sedikit menjadikan pembelajaran menjadi kurang efektif karena peserta didik harus bergantian kelas ketika belajar.

Hambatan lain dalam pembelajaran adalah menekankan nilai-nilai nasionalisme dalam mengingat bahwa kita wajib untuk mengingat tanah kelahiran kita dengan cara ikut serta memperingati hari kemerdekaan Indonesia. Jika di Belanda mayoritas agamanya non muslim, sedangkan siswa yang bersekolah di SIDH Belanda adalah muslim semua, dalam hal ini tantangan bagi seorang guru adalah bagaimana cara kita menanamkan agama yang kental terhadap diri siswa masing-masing dengan cara menerapkan sholat lima waktu di sekolahan, dan mengajarkan perbuatan yang baik sesuai dengan ajaran nabi Muhammad SAW dan tidak melanggar hukum" Allah SWT

b. Hambatan penerapan pendidikan karakter di SIKL Malaysia

Tantangan yang menjadi pokok pelajaran moral di SIKL adalah pengajaran oleh guru dalam kelas., Zarin (1990) menjelaskan beberapa hambatan yang dialami oleh guru seperti kurangnya buku latihan, tidak tersedianya dana untuk kegiatan di luar sekolah dan kurangnya guru spesialis dalam mengajar dan menanamkan pendidikan moral dan pendidikan karakter. ${ }^{18}$

Minimnya sumber daya manusia dan keterbatasan sarana dan prasarana, khususnya dukungan teknologi dan jaringan internet. Pendukung sumber daya manusia meliputi pendidik, peserta didik, dan dukungan orang tua.

Kurangnya fasilitas pembelajaran, seperti media pembelajaran. Sehingga guru sebisa mungkin mengatasi kekurangan media ini dengan membuat bahan replica.

Selain itu, terdapat tantangan-tantangan dalam proses pembelajaran di Sekolah Indonesia Kuala Lumpur yaitu guru diminta untuk memiliki inovasi dan kreatifitas yang tinggi dalam proses pembelajaran, menjaga rasa nasionalisme pada Sekolah Indonesia Kuala Lumpur juga tidak https://youtu.be/lEF03L4ysmE. Pada tanggal 15 Desember 2020 
semudah yang kita bayangkan, karena adanya pengaruh dari budaya Malaysia itu sendiri.

\section{KESIMPULAN}

Berdasarkan uraian diatas, dapat disimpulkan bahwa aktualisasi proses pendidikan pada SILN dalam asimilasi di SIDH Belanda dan SIKL Malaysia yaitu dengan cara menanamkan pendidikan karakter pada masing-masing SILN.

Pendidikan karakter di SIDH Belanda yaitu dilakukan dengan menggunakan metode pembelajaran interaktif, dan metode pembelajaran bermain. Penggunaan metode ini bertujuan untuk mengaktifkan peserta didik dalam pembelajaran, serta mengurangi rasa kebosanan pada peserta didik. Sedangkan pendidikan karakter di SIKL Malaysia yaitu dengan mengadakan beberapa program antara lain: Kelas tanpa piket, Kantin kejujuran, SIKL chanel TV, SIKL expression stage (panggung bakat minat), Librrary explorace, Pojok literasi

Namun dalam mewujudkan pendidikan nasional di SILN terdapat hambatanhambatan dalam pembelajarannya. Hambatan SIDH Belanda antara lain, kurangny tenaga pendidik, pengajaran dalam satu waktu, kurangnya sarana dan prasarana, penyesuaian kondisi geografis, serta sulitnya menekankan nilai-nilai nasionalis. Sedangkan hambatan SIKL Malaysia antara lain, kurangnya media pembelajaran, minmnya guru spesial pendidikan moral, guru kurang inovasi dan kreatif, kurangnya sarana dan prasarana.

\section{DAFTAR PUSTAKA}

Apriana. (2020). Asimilasi Kultural Arab-Melayu Palembang. Medina-Te : Jurnal Studi Islam, 15(2), 202. http://jurnal.radenfatah.ac.id/index.php/medinate/article/view/4248

Hakim, Lukman. (2016). Pemerataan Akses Pendidikan Bagi Rakyat Sesuai Dengan Amanat Undang-Undang Nomer 20 Tahun 2003 Tentang Sistem Pendidikan Nasional, Jurnal EduTech. 2(1), 55. https://doi.org/10.30596/edutech.v2i1.575

Omeri, Nopan. (2015). "Pentingnya Pendidikan Karakter Dalam Dunia Pendidikan.”.Jurnal Manajer Pendidikan, 9(3). 
https:// ejournal.unib.ac.id/index.php/manajerpendidikan/article/view/114 $5 / 0$

PGMI IAIN Kudus. 2020. "Kuliah Lapangan di Belanda-Prodi PGMI.” Diakses dari https://youtu.be/lEF03L4ysmE. Pada tanggal 15 Desember 2020.

Prodi BKPI. 2020. "Kuliah Kerja Lapangan di Sekolah Indonesia Kuala Lumpur Malaysia." Diakses dari https://youtu.be/bZqI8Hdk0Ec. Pada tanggal 15 Desember 2020.

Romli, Khomsahrial. (2015). "Akulturasi dan Asimilasi Dalam Konteks Antar Etnik. Jurnal Ijtimaiyya. 8(1), 3. http://doi.org/10.24042/ijpmi.v8i1.859

SIKL Channel TV. 2020. "Komite Sekolah Mendukung Implementasi Living Curriculum di SIKL." Diakses dari https://youtu.be/65lIffHSr4E. Pada tanggal 15 Desember 2020.

SIKL Channel TV. 2020. "Tanya Jawab-Living Curriculum SIKL Bersama Ketua Tim Penyusun Kurikulum-Ibu Dewi Mariani, S.Pd.” Diakses dari https://youtu.be/K9pEWyhKess. Pada tanggal 15 Desember 2020.

Suhendra, Ade. 2019. Implementasi Kurikulum 2013 dalam Pembelajaran SD/MI Teori dan Aplikasi di Sekolah Dasar/ Madrasah Ibtidaiyyah (SD/MI). Jakarta Timur: Kencana.

Sumintono, Bambang dkk, (2012). "Pendidikan Moral Di Malaysia: Tantangan dan Implementasi Pendidikan Karakter Di Sekolah." Jurnal Pendidikan Karakter, II(1). https://doi.org/10.21831/jpk.v0i1.1308

Sunarti Widyaningsih, Titik. dkk. (2014). Internalisasi Nilai-nilai Karakter Pada Siswa SMP Dalam Prespektif Fenomologis. Jurnal Pembangunan Pendidikan: Fondasi dan aplikasi. 2(2). https://doi.org/10.21831/jppfa.v2i2.2658

Soekanto, Soejono. (1983). Sosiologi: Suatu Pengantar. Jakarta: Rajawali Grafindo Persada.

Tanggu Daga, Agustinus. (2020). Perbandingan Pendidikan Karakter Dalam Kurikulum Sekolah Dasar Di Malaysia, India, dan Indonesia. Jurnal Edukasi Samba (JES). Vol. 4. No. $\quad$ 1. http://jurnalstkipweetebula.ac.id/index.php/jes/articel/view/82

Undang-Undang Republik Indonesia Nomer 20 Tahun 2003, Pasal (3) tentang sistem pendidikan nasional

Wahab, Rochmat. 2010. Menegakkan Sistem Pendidikan Nasional Berdasarkan Pancasila. Yogyakarta : UGM. 